\title{
A PORTRAIT OF THE WRITER AS A RABBIT
}

Unlike rabbits, the stereotypical German is stationary, predictable, and consistent. She plans ahead, stays close to home, and doesn't risk awkward jumps. But rabbits and I-we are übermütig.

Composed of the German preposition über (beyond or above) and mütig, which derives from the noun Mut, or courage, übermütig is commonly translated as carefree, coltish, and slaphappy. But none of these translations captures the adjective's condescending quality. A German who is overly courageous isn't a hero. A German who fails to consider where her jumps will land her is conceited and presumptuous.

Rabbits and I live in the moment; we have a hair trigger and aim high. A truly happy rabbit doesn't take into consideration the powerful strength of her springy hind legs. When she is exuberantly joyful, she puts on "binkies," a series of Jerry Lewis jumps that land her in unforeseeable places. As a result, she bumps into walls and against chairs and slides across hardwood floors. Watching my pet rabbits do their binkies, the stereotypical German in me wants to call out, "Be careful! Don't forget how strong your hind legs are! Don't be übermütig!” But instead I stand back, applaud, and feel inspired.

The binkies are, of course, a form of joyous practice that saves lives in treacherous situations. With their unpredictable jumps and jolts and their ability to suddenly reverse direction, rabbits often manage to fool and escape their pursuers. A well-performed binky can be the difference between life and death.

Staying where I grew up would have killed me. My little Bavarian burrow was stultifying. I devoured the stories passing strangers brought to our home, but there were never enough.

My parents often called me übermütig as a child.

"You are übermütig!" My father would say when I jumped on the couch and ran around the fireplace, skidding on the tiled floor; when I let myself dangle from his elk trophies and climbed on the steel sculptures in the yard.

"This will end in tears!" my mother would warn. And often it did. Tears of embarrassment and anger, because whenever I did fall, my parents would say, "I told you so! You shouldn’t have been so übermütig!" 
As a child I enjoyed digging and dangling, jumping and skidding, but hated the guilt it brought on. I wanted to free myself from my family's fears and from Germany's enervation. We rabbits are masters of escaping enclosures; if necessary we fit into the tightest spaces and can jump up to several times our height.

I got Nils when I was sixteen and didn't know who or what I was (although I was good at pretending I knew). Nils was a small, skinny rabbit, four pounds at the most. He had black, velvety fur and black, beady eyes.

After high school, Nils and I left the German South of our childhood to Hamburg in the far North. In the late afternoons I sat on the piers and watched the sun disappear behind the ships that headed out of the harbor. This was when I knew that there was only one place else to go. While it would soon be night in Hamburg, the day had just begun in America. I wanted to be where Br'er Rabbit fishes with his predators and where Bugs Bunny dresses in drag. I wanted to see the world the way rabbits do: their eyes, positioned strategically on the sides of their heads, allow for an almost 36o-degree panoramic view.

While I figured that in New York my rabbity idiosyncrasies would be welcome, I didn't know what to do about Nils. He was a moody and sensitive rabbit and had already had his share of moves. Afraid that he wouldn't survive a transatlantic journey, I decided to stay put awhile.

Nils was home when I returned from parties and soothed me when I was lovesick. Exasperated with family, friends, and myself, I burrowed my face in his fur. When everything around me was new and unsettling, Nils was there. His binkies brightened starless nights; Nils showed me how to fully enjoy the moment while staying on guard. Most importantly, he taught me to sit down and work. When I paced up and down with pursed lips, he stripped off the wallpaper and chewed on my rugs. But when I sat at my desk to read and write, he calmed down and rolled up into a ball by my feet. The writing of my first stories was accompanied by the sound of him crunching his teeth, the rabbit's equivalent to a cat's purring.

Nils traveled with the summer sun that lit my Hamburg apartment, his tiny black figure melting into the black carpet. After three hours of sunbathing, his fur was scorching like a cast-iron pan. To keep Nils comfortable on the dreary gray days that dominate the German North in the fall and winter, I bought him a white lambskin rug. This lambskin became his passion. $\mathrm{He}$ 
would pluck and pluck at it until he accumulated a large white beard. Then he would sit behind his beard in a corner, like a department store Santa Claus. Thanks to Nils it was Christmas 365 days a year.

Nils lived much longer than I had expected, and it wasn't until after I finished school that I went to New York City for a visit. My first two weeks there only confirmed what I already knew: New York was where I belonged. As if my longing competed with his life, Nils suffered a stroke after my return.

At age eleven, Nils was suddenly unable to move his hind legs. I put him on his lambskin, and his large round eyes, still black and shiny, sank deep into mine.

It seems implausible now, how the old, cranky vet kept refilling the syringe, pumping more and more poison into my four-pound rabbit. As the drug finally began to work, Nils started crunching his teeth. "A reflex," the vet said, dismissively. But I read that cats often purr as they are being put to sleep to either calm themselves or their owners. Maybe it was Nils's last attempt to reassure me that life would continue without him.

The vet asked me to take Nils to the waiting room to give the euthanasia time to work. As I sat on my plastic folding chair, cradling Nils in his lambskin, I sobbed uncontrollably.

"What do you have there?" a woman with a cat in a crate said. My voice contorted by tears, I responded, "A rabbit. He's dead."

"A what?" the woman screeched. "A monkey?"

"A rabbit!" I tried again. Sorrow and tears had turned the German Hase into an Affe.

Friends and family thought it exaggerated that I suffered so much over the death of a rabbit. (In Germany, there are rules to everything. A relative's death warrants one year of suffering; a dog's death a week; and a rabbit's death one day at the most.) But I felt as if with the rabbit, something inside me had died. I am my rabbit. My rabbit is I. There are few people I can understand and who can understand me, but rabbits and I can relate to each other.

Now that my last German rabbit was gone, I had to move on and away. In New York, I thought, I would become who I couldn't be. I was terrified of my future, but nothing could now hold me back. Rabbits and I are anxious yet curious by nature. We are sensitive and hard-bitten. While we are easily startled, we are drawn to explore new, treacherous territory once the imminent danger has passed. 
In the wild, rabbits can survive for months on nothing but branches and roots. Yet they can smell bananas, by far their favorite food, from a distance of two hundred feet. I found the rabbit's versatilities well worth pursuing, but knew that I still had a lot to learn. I had to adapt to my new environs.

After a couple of months in New York, I couldn't stand my rabbitless life any longer. I was stuck and needed a teacher, a friend, a playmate. One rainy day I walked past a pet store in the East Village, where, confined to a small terrarium, sat a large, gray rabbit. The raindrops on the store's window made the rabbit's fur sparkle. Clearly, he must be a treasure, I thought. Hoping to make myself whole again, I bought the poor beast. In a spurt of hope-hope for a sunnier sky, a sunnier life-I named my first American rabbit Sunshine.

A handsome lagomorph with very large ears, one floppy and the other pointing straight up to the sky, Sunshine was a prelude to a whole new learning experience. Not only did I learn more about rabbits; through him I discovered America.

"When are you going to eat him?" my visitors would ask, and astonished by Sunshine's large size they would add, "Do you even own a pot that big?!"

Being a hunter's daughter, I didn't mind their jokes. What I minded was that my American guests would usually follow their jokes with a morbid childhood experience. "One-day-I-came-down-to-the-basement-and-myrabbit-was-dead" was a standard. Other varieties included, "I-had-a-rabbitas-a-child-but-he-died-after-only-eight-days," and "My-rabbit-was-mauledby-our-dog." American rabbits didn't seem to last nearly as long as German rabbits. (I began to fear for my life.) What did I know about my new country? What did my new country know about me? Nothing, really. We were strangers to each other.

In America rabbits are commonly sold in pet stores as Easter gifts for children and then quickly discarded-dropped off in public parks and shelters because people are appalled at their obsession for chewing on wood and rubbery things. The same rabbits that are common house pets in Germany are considered an "exotic species" here. Rabbit health isn't routinely taught in vet school, and the few rabbit-savvy, "exotic" vets in New York charge far more for treating rabbits than their colleagues charge for treating cats or dogs.

When I came to New York in 2001, the House Rabbit Society, a national advocacy and rescue group, operated out of private homes in New York and knew of only two rabbit clinics in the city. (Today HRs occupies a small room 
in East Harlem's Animal Care and Control, and its list of rabbit-savvy clinics in New York has grown to a meager five.)

It is true that the health requirements and drug sensitivities of rabbits differ widely from those of dogs or cats. But calling them "exotic" seemed exotic to me. Like humans, rabbits have adapted to nearly every corner of this world. The swamp rabbit has waterproof fur; he can swim and dive across rivers and hide underwater from predators. The desert cottontail eats cacti and satisfies his need for water by drinking the dew on plants. The brush rabbit can climb trees, and the marsh rabbit makes up for his missing tail with extraordinarily broad feet that help him move over soggy terrain. Most notably, these habitually shy and quiet creatures have adapted to us-our small New York apartments, our big, sudden movements and booming voices.

One of the rabbit's "exoticisms" is that he has a very delicate digestive system. To prevent his system from shutting down, he has to eat constantly. His guts have to be in constant motion. Sunshine, for example, inhaled one large romaine lettuce head, several pieces of broccoli, a carrot, a bowl of oatmeal, and a bucket of hay per day. While this made it easy for me-my rabbits and I have always shared our fridge and pantry-it also meant a considerable strain on my budget, particularly considering the costly veterinary care. I soon began growing dandelion, basil, and carrots in my meager Brooklyn backyard.

Rabbits commonly go into "stasis" if stressed, fed inappropriately, or not fed often enough. They can die within twenty-four hours if they don't eat. It's likely that the "rabbit-in-the-basement" died because his or her needs were neglected. None of this strikes me as particularly exotic.

Yet the perceived exoticism of rabbits coincided with my observation that Americans tend to perceive deviations from their individual experiences and needs as exotic. (Germans, on the other hand, consider deviations as inept, which isn't any better. The label of exoticism and ineptitude both alienate "the other.")

To Americans, I was exotic. "Sabine? And you pronounce the $e$ at the end? That's exotic!"

"Well, actually, Sabine is possibly the most common name for German girls born in the mid-seventies," I would respond. (My parents weren't particularly creative.) "And we Germans-like Italians, Romanians, Russians, Spaniards, etc.- - pronounce each and every letter of a word.” Now I sounded not only exotic, but also blunt, insensitive, pissy even. At the beginning, I did 
not understand the American way of making conversation and the principle that it is always better to have something to say than nothing.

I began to identify with Sunshine's exotic status. I had to remind myself how exotic I must appear to those for whom Germany was a small land that lay sleepily on the globe's back side. It takes years to become an integral part of a new country, and it takes years for the new country to become a part of you. Your body absorbs its new territory much more effortlessly than your soul. Adapting without losing yourself is the main challenge.

I decided to join three rabbit groups and learned that what the American public misses in terms of rabbit expertise and compassion, its rabbit lobbyists more than make up for. In America, there is an A for every Z, a hug for every blow, and plenty of chatter for every stutter. You can either be pragmatic, or you can go overboard. American rabbit enthusiasts tend to do the latter.

Hats off to the House Rabbit Society, and for Etherbun and NYcbuns, two Yahoo groups dedicated to the well-being of lagomorphs. Thanks to them, thousands of rabbits that would have been euthanized are alive today. Never mind that some group members are a bit crazy and militant. For example, a forum discussion about a rabbit's intestinal tumor kept numerous members awake until finally enough prayers were said and pictures of the rabbit's autopsy were posted. A woman's one-line help request sparked more than a dozen outraged replies over several days: "My husband HATES the rabbit and has said if she is still in the house after the new year, he will give her to a chef who cooks rabbits," she wrote on Nycbuns. Some members offered to drive the husband "out to the wilderness and leave him there."

The employment of baby rabbits in a "Sweet Millions" lottery commercial ignited outrage as well. Sweet all right, but were the baby bunnies treated humanely? Does a rabbit suffer when squeezed into a teacup and forced to ride a small carousel? And, more importantly, can a rabbit learn how to ride a little unicycle?

Sunshine had better things to do than ride a unicycle. As if trying to make up for the months he had spent in his tiny terrarium, he was a daredevil at binkies. Rain, snow, or shine, at seven o'clock in the morning he would scratch on the fridge door and demand his morning carrot. Once his white lips had turned emergency-vest orange, he jumped up on the window ledge, squeezed through the bars, and bounced into the backyard. There, he raced around the mulberry tree and ricocheted off the fence and onto the wooden benches. Sometimes, in the middle of his jolt, his behind jerked up as if he 
had suffered a seizure. Then his front legs touched down like a tornado. Chased by an imaginary pursuer, Sunshine zigzagged through the yard. To my surprise, he-the prey-enjoyed being pursued.

For rabbits, life and death are invariably intertwined. It is the powerful strength - and volatility - of their large hind legs that unifies these antipodes. A frightened rabbit sometimes commits suicide in his last moments of life: if he is caught by the wolf, the coyote, or the unkind human, he can jerk his hind legs so violently that he breaks his own back.

After his morning workout, Sunshine would return to the apartment for a hearty brunch. While he ate, he shit, and while he shit, he ate. Rabbits love to cross lines and do things we humans keep strictly separate. (In this case, their line-crossing makes it easy to litter box-train them. Just put some hay into their litter box, and they'll get the idea.)

Carrot-binkies-eating-shitting was Sunshine's routine for a couple of years, until one day he returned from the yard and refused to eat his second breakfast. I grew worried when around noon he only briefly nibbled on some radish greens and then hid in a corner. By evening it was clear that something was seriously wrong.

What I experienced on Sunshine's last day of life now seems emblematic of my first years in New York. Despite an abundance of ingenious stuff-duct tape and Goo Gone still blow my mind-a lot was still missing. There was no pet supply store or vet in my Brooklyn neighborhood, and it took me years to find things like needles and thread. See, we Germans are organized. Each town has at least one major department store within walking distance where one can find anything, from sewing material, cosmetics, and pet supplies, to clothes, cigarettes, books, and Boston lettuce. The departments and their most common items are neatly listed on maps near the escalators. How is it possible that in the greatest city in the world one has to visit three or four different stores and neighborhoods to find the stuff one needs on a daily basis? How was it possible that on a Tuesday night at six p.m. there wasn't a single rabbit vet in all of New York who would see Sunshine?

The large animal hospital by the Fifty-Ninth Street Bridge said they didn't have a rabbit specialist on duty but could try to keep Sunshine alive until the next morning when their specialist returned. The other rabbit-savvy vet had already left her office. 
In the middle of the night, Sunshine's eyes began to tear a thick, milky substance. Although still breathing and sitting up straight, he looked like he was already gone. At two in the morning, Sunshine suffered a seizure and died.

The next morning I dug a grave under the mulberry tree behind the old wooden benches where Sunshine had done his binkies each morning. Placing his limp body into the hole, I was once again astonished by the enormous size of his two hind legs.

It is not a coincidence that Americans lack an appropriate word for übermütig-and that Germans lack a translation for the English word reinvention. But how can one reinvent oneself without being übermütig? If you fall down, pick yourself up and dust yourself off, Americans say. From there I assume one is to walk a different route to avoid falling over the same obstacle twice. In Germany, the proverb Cobbler stick to your lasts, which is hardly known in the U.S., still enjoys great popularity. The Germans' lack of flexibility and their animosity to changes in habits and roles had threatened to suffocate me. In New York I wasn't admonished to stick to my lasts, but I was forced to adapt and unearth what I had in me. Neither one was easy.

Around the time I realized that I needed to loosen up and play, I discovered my kinship with Beatrix Potter. Potter bought her first rabbit, Benjamin Bouncer, at a London bird store and smuggled him into her room in a paper bag. About her second rabbit, Peter Piper, she said, "He was clever at learning tricks, he used to jump through a hoop, and ring a bell, and play the tambourine." Peter Piper is also said to have had a penchant for buttered toast.

Potter recognized the rabbit's ability to alter himself. In The Tale of Peter Rabbit, she showed how her protagonist "squeezed under the gate," skillfully portraying the rabbit's capacity to shrink and stretch parts of his body. Rabbits can be doughy, shapeless lumps one moment and delicately squeeze through fences and into cracks and crannies the next. A rabbit, Potter reminds us, can morph into anything; he can even become dinner: "Don't go into Mr. McGregor's garden," Mrs. Rabbit says to her children. "Your father had an accident there; he was put in a pie by Mrs. McGregor."

This was an encouraging book! Just keep on changing!

\section{Epilogue}

A few years into my time in New York I fell in love with Giovanni GarcíaFenech, a Mexican whose maternal ancestors had come to the New World 
via Italy and Malta. Fenech is the Maltese word for rabbit. The family's coat of arms bears a grinning white rabbit on a green lawn. Naturally, Fenech and I soon got married.

Seven years ago we adopted Teddy from the House Rabbit Society. Teddy is a master of reinvention, and we never grow tired of observing his appearances. He has muddy brown fur with blond patches and looks like a stuffed animal that has been washed with too much soap and too much love. Like Margery Williams's Velveteen Rabbit, it is love that has made Teddy real. The only thing we know about Teddy's previous life is that his owner gave him up because he had to go fight in Iraq. This soldier must have treated Teddy nicely. Why else would he be so addicted to cuddles?

Teddy is old now and very arthritic, but he still plays charades. Sometimes he hunches up and stretches his neck like a turkey. In these moments I am sorely tempted to play along and slip paper frills around his ankles. But I know that as soon as I opened the oven door, Teddy would morph into a loaf of bread, a sack of potatoes, or a Volkswagen Beetle or disappear behind the radiator like a roach.

Because we couldn't keep pace with Teddy's insatiable need for attention, we adopted Pooka. She is sweet and loving, but, unlike Teddy, she's an independent traveler and free spirit. Pooka was named after a line in the movie Harvey ("A fairy spirit in animal form...[t]he Pooka appears here and there, now and then, to this one and that one. A benign but mischievous creature"). With her white fur and large black rings around her eyes, Pooka mostly resembles a panda bear. Sometimes she looks like a Goth whose mascara is running after a good cry. After two hours of binkies and biting our ankles, she turns into a drowsy subway rider, her little head slowly sagging to the side as she dozes off. If a fire truck drives by with its siren blaring, she briefly erects herself and shakes her head in a failed attempt to stay awake. Then she slumps back down in slow motion, leaning on Teddy's shoulder.

I have learned to see the world through my rabbits, but I still wonder who created these odd creatures. And who or what makes me? I am neither superstitious nor religious, but I still regard rabbits as someone's caprice. God is said to have rested on the seventh day-but I suspect it was on that day that He created rabbits, those little useless creatures with their disproportionate legs and ears, their übermütig binkies, and their prowess to transform into anything, even a lost girl's soul. 